\title{
Kristina Čunović
}

Gradska knjižnica Ivan Goran Kovačić, Karlovac, Hrvatska

kristina@gkka.hr

\section{Alka Stropnik}

Knjižnice grada Zagreba, Zagreb, Hrvatska

alka.stropnik@kgz.hr

\section{Kampanje, projekti i programi za promicanje čitanja naglas djeci od najranije dobi}

\section{Stručni rad / report paper}

Primljeno / received 29. 3. 2016. Prihvaćeno / accepted 17. 6. 2016.

DOI: 10.21066/carcl.libri.2016-05(01).0006

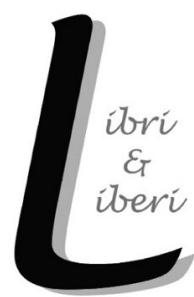

U Hrvatskoj se do 2013. godine provodilo više lokalnih programa koji promiču i potiču čitanje djeci mlađe dobi, no nije postojao projekt ili kampanja na nacionalnoj razini. Potaknuta tim saznanjima, Komisija za knjižnične usluge za djecu i mladež Hrvatskoga knjižničarskoga društva predložila je potencijalnim partnerima da se povodom Europske godine čitanja naglas (2013.) pokrene prva nacionalna kampanja za promicanje čitanja naglas djeci od rođenja u koju bi se sustavno uključili knjižničari, pedijatri i rodilišta te udruge koje se brinu o pravima djeteta od najranije dobi. U ovome radu dajemo pregled svjetskih programa i projekata koji potiču čitanje djeci od rođenja i osnažuju roditelje, a u kojima veliku ulogu imaju narodne knjižnice. Također se ukratko prikazuju programi za poticanje čitanja u Hrvatskoj koji se provode na lokalnoj razini, a posebno je predstavljena hrvatska nacionalna kampanja za čitanje djeci od najranije dobi Čitaj mi! započeta 2013. godine i rezultati ostvareni nakon triju godina djelovanja.

Ključne riječi: rana pismenost, obiteljska pismenost, hrvatska kampanja za poticanje čitanja, nacionalne kampanje i projekti za poticanje čitanja

\section{Uvod}

Tijekom povijesti izmjenjivala su se i nadopunjavala znanja i vještine koje je obuhvaćao pojam pismenosti, a početna vještina potpisivanja doskora je 
nadopunjena vještinama čitanja, pisanja i računanja. Ubrzani razvoj znanosti i tehnologija te eksplozija informacija utjecali su na pojam pismenosti, pa se počelo govoriti o različitim vrstama pismenosti, no temelj svih pismenosti ostala je vještina čitanja, a razvoj svih vrsta pismenosti neodvojivo je povezan s postizanjem boljega uspjeha u školi ili na poslu te s kvalitetnijim sudjelovanjem u životu zajednice. O čitanju u obrazovnome okruženju postoji i relevantna literatura (Visinko 2014).

Svladavanje vještine čitanja počinje od trenutka djetetova rođenja, razvojem predčitateljskih vještina, a ne polaskom u školu. Stoga je važna dobra suradnja i povezanost obitelji, odgojnih i obrazovnih ustanova koje bi trebale djeci pomoći razviti interes za čitanjem iz užitka, pri čemu su knjižnice neizostavni partner. Dijete uči promatranjem i oponašanjem od najranije dobi (Čudina Obradović 2014, Koźmińska 2013, Lonigan 2013, Monaco 2013, Nickel 2013).

Slušanjem i čitanjem djeca spontano uče nove riječi, kako se tvore rečenice, grade i razvijaju priče, djeca uče pratiti priču i koncentrirati se na kraće ili dulje vrijeme. Roditelji imaju priliku stvoriti poticajno obiteljsko okruženje koje je preduvjet za uspješno svladavanje rane i obiteljske pismenosti, a navika čitanja djetetu ne treba prestati njegovim polaskom u školu i svladavanjem vještine čitanja (Stričević 2007).

Naziv „obiteljska pismenost“" uglavnom se odnosi na edukativne programe koji potiču pismenost cijele obitelji, a ponajprije je usmjerena na osnaživanje roditelja i njihovu podršku koju pružaju djeci u stjecanju predčitateljskih vještina te na intenzivniju suradnju obitelji i vrtića/škole. Osim educiranja roditelja, obiteljska pismenost obuhvaća edukaciju odgojitelja i učitelja, odnosno svih koji rade s djecom (Taylor 1983).

Koliko je važno poticajno obiteljsko okruženje vidljivo je iz rezultata Istraživanja čitateljskih interesa i informacijskih potreba građana Hrvatske koji su pokazali da na naviku čitanja djece i mladih utječu navike čitanja odraslih članova obitelji, stalno okruženje tiskanim medijima (novinama, časopisima...) i broj knjiga koji se nalazi u kućnoj knjižnici (Stričević i Jelušić 2011).

Rana pismenost, odnosno ono što djeca nauče o čitanju i pisanju prije nego što počnu samostalno čitati i pisati, izravno je povezana s njihovim uspjehom u čitanju i učenju. Roditelji i odgojitelji u najboljoj su prilici poticati dijete i njegovu radoznalost prema čitanju jer provode najviše vremena s njim. Čitanjem naglas djetetov se rječnik brže razvija, potiče se njegova mašta i razvija sposobnost razumijevanja, a jednostavnom aktivnosti kao što je čitanje naglas roditelj može snažno utjecati i na djetetov kognitivni razvoj. Čitanje djeci emocionalno uključuje roditelja i dijete, a vrijeme provedeno u čitanju vrlo je kvalitetno ispunjeno (Čunović i Stropnik 2015). 
Pedijatri također imaju važnu ulogu u promicanju rane i obiteljske pismenosti jer dopiru do djece iz svih društvenih skupina, dobro poznaju obitelj i u mogućnosti su informirati roditelje o važnosti čitanja, a roditelji imaju povjerenja u njihov stručni autoritet. Neizostavni su partner pri promicanju čitanja narodne knjižnice jer dječji knjižničari znaju važnost njegovanja rane pismenosti, načine na koje se može čitati djetetu, umiju prepoznati, odabrati i preporučiti kvalitetne knjige za djecu i roditelje. Knjižnice svojim programima i uslugama za djecu, (buduće) roditelje i odrasle koji se bave djecom dodatno osnažuju i potiču na čitanje djeci od najranije dobi.

\section{Kampanje, projekti i programi za promicanje čitanja naglas djeci od najranije dobi}

Konvencijom o pravima djeteta UN-a naglašava se pravo svakoga djeteta na puni razvoj njegovih potencijala, pravo na slobodan i otvoren pristup informacijama. U kontekstu dječjega učenja unutar obitelji i cjeloživotnoga učenja, slobodan pristup narodnoj knjižnici jest temeljno ljudsko pravo, a najmlađa djeca ne mogu bez pomoći svojih roditelja i odgojitelja ostvariti prava na knjige i knjižnične usluge. Upravo zato knjižnice, osim ostvarivanja dječjih prava, uzimaju u obzir potrebe odraslih koji se o djeci brinu osvješćujući ih u vezi s važnošću čitanja, knjiga i knjižnica u razvoju maloga djeteta.

Dva su važna dokumenta nastala u okviru IFLA-e (eng. International Federation of Library Associations and Institutions, hrv. Međunarodni savez knjižničarskih društava i ustanova) koji mogu pomoći knjižničarima u radu s djecom i odraslima, odnosno u razvoju rane i obiteljske pismenosti. IFLA-ine Smjernice za knjižnične usluge za djecu u izdanju Hrvatskoga knjižničarskoga društva napominju da su programi i usluge dječjih odjela/knjižnica, između ostaloga, namijenjeni dojenčadi i maloj djeci, roditeljima i drugim članovima obitelji. IFLA-inim Smjernicama za knjižnične usluge za bebe i djecu rane dobi (2008) ciljna su skupina knjižničnih usluga djeca do tri godine, roditelji i drugi članovi obitelji, zakonski skrbnici, odgojitelji, zdravstveni djelatnici, drugi odrasli koji rade s djecom, knjigama i medijima. Osim opisanih usluga, programa, građe, prostornih uvjeta, osoblja i dr. u Smjernicama je prikazano dvadesetak primjera dobre prakse iz Hrvatske i svijeta, a one sadrže i Popis za samoprovjeru. Smjernice imaju za cilj unaprijediti kvalitetu rada s djecom obraćajući se u prvome redu dječjim knjižničarima, roditeljima, obitelji, odgojiteljima, ali i pedijatrima. Preporučuje se da uvođenje usluga za bebe i djecu rane dobi narodne knjižnice uključe u svoju misiju kako bi osigurale poticajno i sigurno okruženje za razvoj i učenje, odnosno pomogle u razvoju pismenosti od rane dobi. 
U svijetu je uobičajena praksa da dječje knjižnice i predškolske ustanove na nacionalnoj razini, a gdje je to moguće i u lokalnoj zajednici, surađuju s pedijatrima i rodilištima kako bi čitanje naglas postalo dio svakodnevnih aktivnosti djece od najranije dobi.

Svaka država ima jedinstvenu situaciju, uvjete i mogućnosti za poticanje obiteljske i rane pismenosti, pa se u skladu s time osmišljavaju i organiziraju projekti i kampanje na nacionalnoj i lokalnoj razini. Poučavanje i razvijanje vještina obiteljske i rane pismenosti posebice je važno u zemljama s velikim udjelom imigranata u ukupnome broju stanovnika. Slijedom toga prvi projekti za razvoj obiteljske pismenosti krenuli su iz multikulturnih okruženja. Rad s roditeljima, podrška i poticanje obiteljske pismenosti jednako su važni kao i poticanje dječjih predčitateljskih vještina. Kasnije prepoznavanje nedostatka predčitateljskih vještina, ponekad tek pred djetetov polazak u školu, često rezultira težim svladavanjem školskoga programa. Prepoznata je i velika važnost knjižničara koji su nezaobilazni u svim primjerima programa i projekata koji promiču čitanje djeci od najranije dobi.

\section{Born to Read}

Born to Read program je britanske nacionalne dobrotvorne ustanove Beanstalk koji pruža podršku roditeljima u razvoju dječjih čitateljskih vještina. Beanstalk je osnovan 1973. godine u Ujedinjenome Kraljevstvu pod nazivom Volunteer Reading Help sa zadaćom da pronalazi i poučava volontere koji će promicati i poticati čitanje mlađih osnovnoškolaca. Zajedno s organizacijom Save the Children UK radi na promicanju čitanja i pismenosti. Osmišljavanje i provođenje takvih programa potaknuli su rezultati mnogih istraživanja koja su pokazala da djeca koja čitateljske vještine ne savladaju tijekom osnovne škole na maturi imaju vrlo nisku razinu pismenosti, a to otežava daljnje školovanje i zaposlenje.

\section{Stiftung Lesen}

Stiftung Lesen neprofitna je organizacija, odnosno zaklada koja za cilj ima promicanje poticanja čitanja. Od 1988. zaklada je razvila brojne projekte koji se održavaju pod pokroviteljstvom predsjednika Njemačke Republike. Uz provođenje istraživanja i pokusnih projekata na saveznoj i republičkoj razini u središtu je rada zaklade suradnja s vrtićima, školama, knjižnicama, knjižarama i medijima. O važnosti čitanja poučavaju se djeca, njihovi roditelji i drugi odrasli koji rade s djecom, a više programa usmjereno je na roditelje i djecu, odnosno na razvoj obiteljske pismenosti (Ehmig i Seelmann 2013). 


\section{Reach Out and Read}

Program Reach Out and Read započeo je s radom 1989. u Bostonskoj gradskoj bolnici (Boston City Hospital), u Sjedinjenim Američkim Državama. Do 2001. program se proširio na cijeli SAD, u 1500 gradova. Program je osmišljen tako da liječnici, medicinske sestre, odnosno svi sudionici programa koji su prošli edukaciju, djeluju na redovnim pedijatrijskim pregledima u tri koraka. Pri prvome dolasku u bolnicu roditelje se informira o važnosti čitanja naglas, a na svakome sljedećemu pregledu, u dobi od šest mjeseci do pet godina, dijete dobiva novu knjigu za kućnu knjižnicu. Knjige su dostupne na četrnaest jezika, a godišnje ih se podijeli preko 1,6 milijuna. Mrežne stranice programa bogate su sadržajem za poticanje pismenosti i promicanje čitanja, sadrže popise preporučenih knjiga, savjete i primjere kako čitati djetetu i dr. Istraživanja koja su pratila primjenu programa pokazala su da djeca obuhvaćena programom u predškolskoj dobi imaju bogatiji rječnik od svojih vršnjaka. Trenutno je programom obuhvaćeno više od četiri milijuna djece, a posebna pažnja posvećena je djeci iz obitelji slabijega imovinskoga statusa.

\section{Bookstart}

Projekt Bookstart započeo je 1992. u Birminghamu, a u početku je obuhvaćao tek 300 djece, dok se već godinama projektom godišnje obuhvati više od 2 milijuna djece i roditelja. Projektom se potiče obiteljska pismenost, čitanje djeci od najranije dobi i pomaže u osnaživanju roditelja (Chadwick 2013). Na mrežnim stranicama projekta napisane su upute kako doći do paketa Bookstart Baby bag s dvjema slikovnicama i promotivnim materijalima za roditelje. Početni paket namijenjen je djeci od rođenja do prve godine, a donosi ga patronažna služba pri prvome posjetu. Također se roditelje upućuje na mrežne stranice knjižnica i savjetuje da djecu što ranije učlane u knjižnicu, uz napomenu da nema nadoknade za uništene slikovnice. U drugome koraku projekta roditelji za dijete od dvije do četiri godine dobivaju Bookstart Treasure bag, torbu koja sadrži dvije slikovnice i publikacije za roditelje sa savjetima za čitanje. Booktouch ili Bookshine dodatci su osnovnomu paketu za djecu s oštećenim vidom ili sluhom. Također postoje i dodatci za djecu s razvojnim i motoričkim smetnjama.

\section{All of Europe Reads to Kids}

All of Poland Reads to Kids Foundation s radom je započela 1998. godine. Svrha zaklade bila je pružiti podršku emocionalnomu zdravlju djece i mladih u Poljskoj edukativnim, organizacijskim i promotivnim aktivnostima. Zaklada je 2001. godine pokrenula kampanju All of Poland Reads to Kids koja radi na podizanju svijesti o važnosti svakodnevnoga čitanja djeci. U lipnju 2002. godine zaklada je organizirala Prvi nacionalni tjedan čitanja djeci u koji se uključilo 150 
sela i gradova. Sljedeće godine pokrenuli su dva edukativna programa, Reading Schools i Reading Kindergartens te je potpisana izjava All of Europe Reads to Kids kojom se promiče čitanje od najranijega djetinjstva u svim okruženjima, kod kuće, u vrtićima i školama. Danas u Poljskoj djeluje preko 7700 koordinatora i voditelja koji rade na poticanju čitanja u više od 3000 mjesta.

\section{Nati per leggere}

Talijanski nacionalni projekt Nati per leggere započeo je 1999., a osmislili su ga, te ga zajednički i danas provode, Associazione Culturale Pediatri (Udruga pedijatara), Associazione Italiana Biblioteche (Udruga talijanskih knjižnica) i Centro per la Salute del Bambino (Centar za dječje zdravlje - neprofitna udruga koja se bavi istraživanjima, izobrazbom i promicanjem zdravlja i razvoja djeteta od začeća do adolescencije). Projekt je decentraliziran, organizira se i provodi na lokalnoj razini s mogućnošću prilagođavanja ovisno o potrebama, ali i mogućnostima lokalne zajednice kako bi broj djece obuhvaćene projektom bio što veći. Istovremeno djeluje više od 500 lokalnih projekata, u kojima sudjeluje 8000 profesionalaca (knjižničara, pedijatara, socijalnih i zdravstvenih djelatnika, odgojitelja i dr.), a njime je obuhvaćeno oko 35 posto ukupnoga stanovništva Italije. Nacionalni odbor projekta broji pet knjižničara i pet pedijatara koji usklađuju i odobravaju lokalne aktivnosti s nacionalnim programom, brinu se o odnosima s javnošću na nacionalnoj razini, održavaju mrežne stranice projekta, izrađuju promotivne materijale, sastavljaju popis primatelja e-pošte i educiraju promotore projekta na lokalnoj razini. U sklopu projekta tiskan je vodič za roditelje i buduće čitatelje, a stalno se odabiru i izrađuju popisi kvalitetnih knjiga za čitanje djeci mlađoj od šest godina. Odbor skrbi o popunjavanju zbirki za djecu u narodnim knjižnicama i o unapređenju knjižničnih usluga za djecu rane dobi. U suradnji s nakladnicima odbor dogovara snižene cijene određenih, preporučenih naslova koje pedijatri daruju djeci. Guarda che faccia! slikovnica je koju su osmislili pedijatri. Slikovnica je prevedena i pod nazivom Gledaj ova mala slatka lica!, a dijele ju pedijatri u Dubrovačkoj županiji (Radonić i Stričević 2009).

U Španjolskoj se od 2002. godine provodi nacionalni projekt Nascuts per llegir koji je nastao po uzoru na talijanski.

\section{Born to Read, Read to Bond}

Born to Read, Read to Bond program je koji se provodi u Singapuru, njegova je svrha promocija cjeloživotnoga učenja, povezivanja roditelja i djece od rođenja do treće godine uz stvaranje čvrstih obiteljskih veza. Program je 2002. godine osmislio National Library Board (Odbor nacionalne knjižnice) u suradnji s Ministry of Community Development and Sports (Ministarstvom razvitka zajednice i 
sporta). Statistički podaci pokazali su da, iako se posuđuje mnogo dječjih knjiga u knjižnicama, djeca su rijetki posjetitelji knjižnica, jer umjesto njih posuđuju roditelji. Program je osmišljen tako da se njime povezuju djeca i roditelji, usmjeren je na kvalitetno provođenje vremena u knjižnici uz druženje, čitanje, biranje i posudbu knjiga. Kao jedan od pokazatelja uspješnosti programa navodi se povećan broj učlanjene djece. Program započinje u bolnicama u kojima roditelji mogu predbilježiti novorođenu djecu za sudjelovanje u njemu, nakon čega djeca odmah dobivaju člansku iskaznicu knjižnice, torbu za čitanje i štednu knjižnicu. Roditelji dobivaju popust na radionice o roditeljstvu.

\section{FLY Pilot Project}

Dr. Gabriele Rabkin inicirala je u Hamburgu FLY Pilot Project, odnosno pokusni projekt obiteljske pismenosti. Projekt je započeo 2004., trajao je do 2009. godine, a uključivao je sudjelovanje roditelja djece predškolske dobi i učenika prvoga razreda. U suradnji s UNESCO-ovim institutom za cjeloživotno učenje i Državnim institutom za obučavanje učitelja i razvoj škola projekt je obuhvatio osam škola i jedan vrtić u socijalno depriviranim zajednicama u Hamburgu s velikim brojem useljenika. Ciljevi projekta bili su promocija vještina rane pismenosti, unapređenje roditeljskih vještina pismenosti, poboljšanje suradnje roditelja i škole, veća uključenost roditelja i poučavanje učitelja i edukatora. Projekt je, kao dio Programa za unapređenje djece $i$ mladih s useljeničkim podrijetlom, pet godina financirala Njemačka državna komisija za planiranje obrazovanja i poticanje istraživanja. To je rijedak primjer pokusnoga projekta nastaloga privatnom inicijativom koji je integriran i koji je postao dijelom državne politike. Od 2013. godine provodi se u 70 škola, odnosno 260 skupina za učenje.

\section{Reading the world - Early childhood library project}

Instituto Brasil Leitor (Brazilski institut za čitanje) neprofitna je nevladina organizacija koja je od 2004. godine u više od 70 knjižnica diljem Brazila pokrenula Reading the world, projekt za poticanje čitanja djeci od rođenja do šeste godine. Glavni cilj projekta bio je dovesti dijete u knjižnicu, prostor u kojemu će moći slušati, istraživati, komunicirati i učiti o svijetu oko sebe igrajući se i družeći se s knjigom. Osim toga, dodatnu edukaciju prošli su roditelji, djelatnici knjižnica i volonteri koji rade s djecom.

\section{Celé Česko čte dětem}

Češki program za poticanje čitanja djeci od rođenja Celé Česko čte dětem 2006. godine pokrenula je Eva Katrušáková, a temelji se na poljskome modelu poticanja čitanja. Poljska i Češka zaklada zajednički su 2011. godine organizirale Prvi međunarodni tjedan čitanja djeci. 


\section{Visa Lietuva skaito vaikams}

Zaklada Mažojo Princo Fondas (Mali princ) potaknuta poljskim i češkim nacionalnim kampanjama te primjerima dobre prakse u poticanju čitanja djeci mlađe dobi inicirala je pokretanje litavske kampanje na nacionalnoj razini. Kampanja Visa Lietuva skaito vaikams, odnosno All of Lithuania Reads to Kids, službeno je započela s provedbom u travnju 2012. godine na konferenciji „Educating by Reading“.

\section{Programi za poticanje čitanja u Hrvatskoj}

U Hrvatskoj već niz godina postoje brojni primjeri poticanja pismenosti i čitanja djeci od najranije dobi, no do 2013. godine i početka nacionalne kampanje Čitaj mi! svi su djelovali na lokalnoj razini. Svaka lokalna zajednica organizirala je različite aktivnosti u skladu sa svojim mogućnostima, od paketa za novorođenčad, besplatnoga upisa djece u knjižnice ili darovanja prve slikovnice. Svim tim programima i projektima za poticanje čitanja bilo je zajedničko to da su ih potaknuli knjižničari.

Koprivnička knjižnica i čitaonica Fran Galović 1999. godine u suradnji s Neonatološkim odjelom Opće bolnice Dr. Tomislav Bardek pokrenula je projekt Knjige za bebe. Sva djeca rođena u tjednu obilježavanja Međunarodnoga dana pismenosti dobila su besplatno petogodišnje članstvo u knjižnici, a roditelji edukativne materijale o važnosti poticanja rane pismenosti. Od početka provođenja programa cilj je bio da svako novorođenče na poklon dobije svoju prvu slikovnicu, što je omogućeno 2003. godine otkada, zahvaljujući financijskoj potpori Podravke i Grada Koprivnice, slikovnicu dobivaju sva djeca rođena u koprivničkome rodilištu. Paket Knjige za bebe upotpunjen je 2008. novim sadržajima. Uz brošuru i prijavnicu za upis u knjižnicu paket sadrži slikovnicu koju je izdala nakladnička kuća Mozaik knjiga, a cjelokupni sadržaj upakiran je u male platnene torbe. Godišnje se podijeli oko 1000 paketa koji su djelomično financirani javim sredstvima grada i županije, a djelomično iz privatnoga sektora i donacijama. Od 2003. do kraja 2012. godine u projekt Knjige za bebe bilo je uključeno 10100 novorođene djece.

Projekt Čitajmo im od najranije dobi započeo je 2004. godine u deset zagrebačkih dječjih vrtića. Voditeljica projekta bila je dr. sc. Ivanka Stričević, koja je ujedno bila i predsjednica Komisije za knjižnične usluge za djecu i mladež HKD-a, a suradnica na projektu Hela Čičko, zamjenica predsjednice Komisije. Cilj projekta bio je informirati i educirati odgojitelje i roditelje o ranome čitanju djeci i izboru kvalitetne literature za djecu. Tijekom trajanja projekta održano je niz predavanja i radionica za odgojitelje dječjih vrtića i zainteresirane roditelje u kojima su upoznati sa znanstvenim spoznajama u području čitanja i razvijanja pismenosti djece od 
najranije dobi, s projektima poticanja rane pismenosti te načinima čitanja i izborom knjiga za djecu. Projekt je financijski podržao Gradski ured za obrazovanje, kulturu i šport Grada Zagreba. Sudionici radionica izrazito su pozitivno ocijenili važnost informiranja o ranoj pismenosti i čitanju djeci od najranije dobi. Odgojitelji su prepoznali važnost predavanja za budući profesionalni rad, a roditelji su spoznali vrijednost čitanja u druženju s djecom. Projekt je nastavljen u 2005. godini, u deset dječjih vrtića koji nisu bili obuhvaćeni tijekom prethodne godine (Stričević i Čunović 2013).

Od 2005. do 2011. godine sva djeca rođena u Sisku upisivana su u Narodnu knjižnicu i čitaonicu Vlado Gotovac prema podacima o novorođenima dobivenima iz Matičnoga ureda. Na adrese su slane prigodne čestitke i letci o knjižnici, njezinim uslugama za najmlađe s tekstom za roditelje o važnosti čitanja od najranije dobi. U prilogu je bila počasna članska iskaznica za dijete koja je vrijedila godinu dana. Dugogodišnja praksa prekinuta je zbog donošenja Zakona o zaštiti osobnih podataka i nemogućnosti dobivanja popisa novorođenih, no roditelje se putem mrežnih stranica knjižnice poziva na „aktiviranje“ besplatnoga upisa djeteta, a poziv objavljuju i mediji. Projekt dijeljenja paketa informativno-edukativnoga sadržaja roditeljima novorođene djece pokrenut je u suradnji s Hrvatskim čitateljskim društvom u rujnu 2009., a nastavljen je u veljači 2010. godine. Paketi dijeljeni u rodilištima bili su pripremljeni u suradnji s udrugom RODA (Roditelji u akciji), knjižnicom te Komisijom za knjižnične usluge za djecu i mladež HKD-a. Tijekom 2012. godine novorođena djeca besplatno su upisivana tijekom Mjeseca hrvatske knjige.

U Karlovcu je partner projekta Bebe u knjižnici Grad Karlovac koji od 2009. godine sufinancira besplatan upis djece do godine dana u knjižnicu te kupnju strunjača, jastuka za bebe, didaktičkih igračaka, slikovnica za najmlađu djecu i druge opreme za malu igraonicu. Osim toga, uspostavljena je suradnja s rodilištem u karlovačkoj Općoj bolnici. Svaka rodilja dobiva čestitku i letak na kojemu su informacije o programu Bebe u knjižnici s pozivom za besplatno učlanjenje djeteta.

Hrvatsko čitateljsko društvo 2007. godine pokrenulo je projekt Čitajmo im od najranije dobi temeljen na rezultatima istoimenoga projekta provedenoga $\mathrm{u}$ Zagrebu 2004. i 2005. godine. Uz pomoć sredstava dobivenih od Ministarstva kulture RH-a u Osijeku i Zadru organizirana su predavanja i radionice za odgojitelje u vrtićima i roditelje djece predškolske dobi. S obzirom na to da je cilj projekta bio proširiti svijest o važnosti čitanja djeci od njihova rođenja u cijeloj Hrvatskoj, na radionicama su izabrani potencijalni voditelji radionica o ranoj pismenosti i čitanju za koje je kasnije organizirana posebna jednodnevna radionica. Potaknuto dobrim rezultatima projekta, Hrvatsko čitateljsko društvo odlučilo se za još aktivniji i izravniji pristup poticanju i promoviranju važnosti čitanja djeci od najranije dobi. 
U suradnji s udrugom RODA, gradskim knjižnicama i Komisijom za knjižnične usluge za djecu i mladež HKD-a osmišljen je paket s informativno-edukativnim materijalima koje su roditelji djece rođene u tjednu kada se obilježava Međunarodni dan pismenosti dobili u rodilištu. Paket je sadržavao informativni letak o potrebi čitanja djeci od najranije dobi, kratki popis kvalitetnih slikovnica za djecu do treće godine (objavljenih u Hrvatskoj u proteklih nekoliko godina), slikovnicu koju mogu ,čitati“ i bebe, letak Ne! Po guzi!, prigodnu čestitku, besplatnu jednogodišnju člansku iskaznicu za lokalnu gradsku knjižnicu i promotivni letak o Hrvatskome čitateljskome društvu. U projekt su bili uključeni Bjelovar, Osijek i Sisak.

Važnost knjižnice kao partnera u poticanju i promicanju rane i obiteljske pismenosti posebno je istaknuta 19. ožujka 2007. godine na stručnome skupu „Roditelji s bebama i malom djecom - dobro došli u knjižnicu!“‘. Skup su organizirali Komisija za knjižnične usluge za djecu i mladež HKD-a i Knjižnice grada Zagreba, a održan je u Knjižnici Medveščak. Na njemu su pozvani izlagači govorili o važnosti i poticanju „predškolskoga čitanja“, središnjemu mjestu knjižnice u funkciji jačanja roditeljskih kompetencija, dječjoj knjižnici kao partneru u projektu Rođeni za čitanje, a predstavljena je i radna verzija IFLA-inih Smjernica za knjižnične usluge za bebe i djecu do tri godine te su prikazani brojni primjeri dobre prakse iz hrvatskih narodnih knjižnica.

Dubrovnik je 2008. godine započeo s provedbom projekta Rođeni za čitanje koji potječe od talijanskoga projekta Nati per leggere. Nositelji su projekta u Italiji knjižničari i pedijatri, dok je talijanska iskustva u Hrvatsku prenijela Marija Radonić, članica Hrvatskoga pedijatrijskoga društva. Projekt, uz nositelje, uključuje volontere čitanja, pedagoge, učitelje, društveno-kulturne djelatnike, obiteljske centre, centre za odgoj, izdavače i knjižare. Cilj je projekta potaknuti roditelje na čitanje djeci od najranije dobi jer čitanje naglas u dobi od šest do dvanaest mjeseci razvija jaču privrženost onoga tko čita i onoga tko sluša, smiruje, pruža osjećaj sigurnosti te stvara navike slušanja. Također, čitanje naglas potiče stvaranje ljubavi prema čitanju i znatiželje prema knjigama te potiče razvoj govora, pažnje, mašte, percepcije i kreativnosti. Do sada su za projekt tiskane dvije slikovnice za djecu rane dobi, a u tisku je i treća. Prva slikovnica Gledaj ova mala slatka lica namijenjena je djeci do prve godine, slikovnica Idem spavati djeci od druge do treće godine, a slikovnica je Što radi moj tata za četverogodišnjake. Tisak slikovnica financirao je Grad Dubrovnik (Radonić i Stričević 2009).

\section{Hrvatska nacionalna kampanja Čitaj mi!}

Komisija za knjižnične usluge za djecu i mladež Hrvatskoga knjižničarskoga društva provela je 2011. godine istraživanje u hrvatskim narodnim knjižnicama 
o knjižničnim uslugama u narodnim knjižnicama za djecu rane dobi i roditelje. U gotovo polovici od 61 knjižnice koja je sudjelovala u istraživanju, provode se usluge za djecu rane dobi i njihove roditelje, a čak 62,3 posto knjižnica planira uvesti neku od knjižničnih usluga koje dosad nisu provođene (primjerice, besplatno članstvo za malu djecu, predavanja za roditelje, igroteku, informativne materijale o važnosti čitanja naglas i dr.). Rezultati istraživanja pokazali su da se u Hrvatskoj u pojedinim lokanim zajednicama intenzivno i uspješno potiče čitanje djece od najranije dobi, ali i da nedostaje kampanja za rano čitanje djeci na nacionalnoj razini koja bi obuhvatila sve dječje knjižnice, pedijatre i rodilišta, udruge civilnoga društva i podizala svijest javnosti o važnosti čitanja djeci. Potaknuta rezultatima istraživanja, Komisija za knjižnične usluge za djecu i mladež HKD-a predložila je potencijalnim partnerima da se povodom Europske godine čitanja naglas (2013.) pokrene prva nacionalna kampanja za promicanje čitanja naglas djeci od rođenja. Komisija za knjižnične usluge za djecu i mladež s Hrvatskim pedijatrijskim društvom, hrvatskim UNICEF-om, Hrvatskim čitateljskim društvom i Hrvatskom udrugom istraživača dječje književnosti 2013. godine pokrenula je nacionalnu kampanju Čitaj mi! da bi kontinuiranim promicanjem rane pismenosti i kulture čitanja u obitelji usluge za bebe, djecu rane dobi i njihove roditelje postale dio stalnih knjižničnih programa u narodnim knjižnicama. Kampanja se nastavila 2014. godine pod pokroviteljstvom Ministarstva kulture i Ministarstva socijalne politike i mladih, a u kampanju su se 2015. godine uključili Hrvatsko logopedsko društvo i Zaklada Nacionalne i sveučilišne knjižnice u Zagrebu.

Tijekom triju godina trajanja kampanje Čitaj mi! organizirano je mnogo kreativnih i maštovitih događanja te su održana brojna predavanja za roditelje o važnosti čitanja djeci naglas i razvoju rane pismenosti. Organizirane su izložbe kvalitetnih slikovnica na dječjim odjelima, čitanje priča za laku noć na lokalnim radiopostajama, čitanje priča u knjižnicama, gradonačelnici su čitali u knjižnicama i na gradskim trgovima, a na pojedinim dječjim odjelima bolnica otvoreni su kutići sa slikovnicama. Održano je nekoliko javnih predstavljanja kampanje na gradskim trgovima, u gradskim vijećnicama, na stručnim skupovima logopeda i odgojitelja. Koprivnička i ogulinska knjižnica poklanjale su u rodilištu informativnoedukativne materijale (letak o potrebi čitanja djeci od njihove najranije dobi i slikovnicu) te člansku iskaznicu za bebu. U pedijatrijskim ordinacijama i predškolskim ustanovama više gradova otvorene su male libroteke, police sa slikovnicama i knjigama za djecu koje su donirali nakladnici, knjižnice i roditelji. U organizaciji Hrvatskoga čitateljskoga društva organiziran je okrugli stol „Čitanje naglas“ povodom Međunarodnoga dana pismenosti (8. rujna 2013.) koji je okupio stručnjake iz područja čitanja i poticanja čitanja djeci od najranije dobi, kako bi se društvo u cjelini još jedanput upozorilo na važnost čitanja naglas. 
UNICEF je u suradnji s pedijatrima i knjižničarima kampanjom nastojao knjigu učiniti dostupnom svakomu djetetu, posebno obiteljima koje žive u teškim materijalnim uvjetima, stoga je u gospodarski nerazvijenijim i siromašnijim krajevima Hrvatske tijekom redovitih sistematskih pregleda u pedijatrijskim ambulantama organizirao besplatnu podjelu slikovnica za bebe Gledaj ova slatka mala lica. Također je, u suradnji s poznatim UNICEF-ovim fotografom Giacomom Pirozzijem, fotografirana obitelj koja čita djeci, a koja se kasnije našla i na velikim plakatima.

U kampanju su se aktivno uključili i nakladnici sniženjem cijena slikovnica i posebnim akcijama, tiskanjem letaka i metra koji prikazuje odabir slikovnica u skladu s dječjim razvojem. Nakladnici su također donirali slikovnice za fotografski natječaj kampanje tijekom kojega su roditelji i drugi odrasli u obitelji poslali fotografije i videosnimke koji prikazuju odraslu osobu i dijete/djecu za vrijeme aktivnosti čitanja ili djecu do četvrte godine koja sama „čitaju“. Od 1. srpnja do 1. rujna 2013. godine natječaj kampanje Čitaj mi! spojio se s fotografskim natječajem Hrvatskoga čitateljskoga društva Smiješak... Čitajte!

U sklopu kampanje Čitaj mi! pokrenuta je i internetska stranica <www. citajmi.info $>$ namijenjena roditeljima i svima koji su svjesni važnosti čitanja djeci od rođenja. Stranica sadrži informacije o tome zašto je važno djeci čitati naglas, besplatne materijale (plakat, letak, logo) za promidžbu čitanja naglas djeci od rođenja, nagradni natječaj koji podržavaju nakladnici svojim izdanjima za najmlađu djecu, popis vrijednih slikovnica za pojedinu dječju dob i mnoge druge korisne sadržaje. Informacijski stručnjaci osmišljavaju i prenose nove spoznaje iz područja rane pismenosti i na društvenim mrežama, Facebooku i Twitteru, a objave prate i dijele roditelji, knjižničari i knjižnice, obiteljski centri, književnici, nakladnici i mnogi drugi.

Cilj nacionalne kampanje Čitaj mi! bio je potaknuti roditelje i ostale odrasle osobe koje se u svojemu radu bave djecom da s čitanjem započnu već od djetetova rođenja kako bi čitanje postalo dio svakodnevnoga ugodnoga druženja djece i roditelja i kako bi ono pridonijelo stvaranju posebne emocionalne veze između njih. Jednako tako za cilj je postavljeno i poticanje na što raniji dolazak najmlađe djece i roditelja u lokalnu narodnu knjižnicu te upoznavanje roditelja s dobrobitima čitanja naglas, prikladnim načinima i vremenom čitanja djeci najranije dobi, s vrijednom slikovnicom u svakoj fazi djetetova razvoja.

Komisija za knjižnične usluge za djecu i mladež, kao inicijator nacionalne kampanje za poticanje čitanja naglas djeci od najranije dobi Čitaj mi!, također je uspjela kampanjom pokazati važnost rane i obiteljske pismenosti, a tijekom dosadašnjega trajanja kampanje dječji odjeli narodnih knjižnica pokazali su 
da su važan i nezaobilazan organizator mnogih programa za djecu rane dobi te važna poveznica između raznih ustanova, udruga i volontera. Dječji knjižničari pokazali su se vrsnim stručnjacima koji ustrajno rade na promjeni percepcije dječje književnosti u javnosti odabirom kvalitetnih tekstova s odgovarajućim ilustracijama. Kao rezultat višegodišnje vidljivosti kampanje u javnosti (veliki plakati na javnim površinama, autobusnim postajama, kolodvorima, u trgovačkim centrima...) ističe se porast broja upisane djece u sve narodne knjižnice u Hrvatskoj, kao i broja posjeta roditelja s djecom te sudjelovanja u knjižničnim programima.

U narednome se periodu kampanji planira osigurati sustavnu financijsku podršku nadležnih ministarstava da bi nastavili realizaciju aktivnosti na nacionalnoj razini, edukaciju volontera te izradu promidžbenih materijala. Cilj je kampanje da u sljedećih nekoliko godina svako novorođeno dijete dobije svoju prvu slikovnicu, a kasnije, na redovitim pedijatrijskim pregledima s tri godine odnosno šest godina drugu i treću knjigu.

Prema mišljenjima mnogih stručnjaka ovo je jedna od najbolje osmišljenih, inovativnih hrvatskih akcija koja promiče čitanje i knjigu u obiteljskome okruženju, a suradnja brojnih partnera doprinijela je širenju svijesti o važnosti čitanja naglas i poticanju rane i obiteljske pismenosti na lokalnoj i nacionalnoj razini. S istim ciljem i dalje će se raditi na provođenju aktivnosti u sklopu kampanje Čitaj mi! jer je dobra ideja ujedinila mnoge: knjižničare, pedijatre, književnike, nakladnike, odgojitelje, logopede, brojne volontere i sve ostale koji svojim radom svakodnevno doprinose dječjoj dobrobiti.

\section{Umjesto zaključka: postignuća kampanje Čitaj mi! od 2013. do 2016.}

Partneri su kampanje: Hrvatsko čitateljsko društvo, Hrvatsko knjižničarsko društvo - Komisija za knjižnične usluge za djecu i mladež, UNICEF, Hrvatsko pedijatrijsko društvo, Hrvatska udruga istraživača dječje književnosti, Hrvatsko logopedsko društvo, a potporu joj pružaju Ministarstvo socijalne politike i mladih, Ministarstvo kulture, Zaklada Nacionalne i sveučilišne knjižnice i drugi. Ostvarena je i dobra suradnja s mnogim nakladničkim kućama.

U više od 670 aktivnosti sudjelovalo je oko 30000 djece i roditelja, a programi su realizirani u 200-tinjak narodnih i školskih knjižnica s preko 3000 volontera.

Uz financijsku potporu UNICEF-a tiskano je 4000 slikovnica za bebe Gledaj ova mala slatka lica koje su nakon predavanja prim. mr. sc. Marije Radonić, pedijatrice dubrovačke Opće bolnice, podijeljene pedijatrima u Šibensko-kninskoj i Karlovačkoj županiji, a potom u Sisačko-moslavačkoj, Virovitičko-podravskoj i Vukovarskoj županiji. 
Stručnjaci različitih područja (pedagozi, psiholozi, logopedi, knjižničari) održali su predavanja za roditelje o važnosti čitanja djeci u Karlovcu, Zadru, Koprivnici, Bjelovaru, Vukovaru i drugim gradovima.

Otvoreno je više malih pokretnih knjižnica - Zbirčice i Male libroteke - u dječjim vrtićima iz kojih se kući posuđuju slikovnice u Zadru, Rijeci, Velikoj Gorici, Novoj Gradiški; također je otvoreno niz malih knjižnica u pedijatrijskim ambulantama i domovima zdravlja u Sisku, Prelogu, Bjelovaru, Koprivnici, Ozlju, Splitu, Vukovaru i Čakovcu.

Za promidžbu kampanje tiskano je 10000 letaka i 2100 plakata B1.

Ogledalovirtualnevidljivostimrežnajestranica $<$ www.citajmi.info $>$, a aktivnosti u vezi s njom obuhvaćaju održavanje stranice i osvježavanje popisa preporučenih slikovnica kao i najave događanja u okviru kampanje u cijeloj Hrvatskoj.

Na Facebookovoj stranici, <www.facebook.com/CitajMi>, više je od 2000 objavljenih informacija i 5200 lajkova, a na Twitteru, <https://twitter.com/citaj_ mi>, je objavljeno gotovo 300 tweetova, dok stranicu prati 144 ,poklonika“.

Na mrežnoj stranici prijavljeno je više od 560 fotografija i videoisječaka za nagradni fotografski natječaj kampanje, a u Dubrovniku je snimljena milenijska fotografija Čitaj mi! te je više od 90 slikovnica podijeljeno obiteljima koje su sudjelovale u fotonatječaju.

Svake godine 14. veljače obilježava se Međunarodni dan darivanja knjiga, a do ožujka 2016. godine prikupljeno je više od 9000 slikovnica u velikoj akciji darivanja slikovnica „Čitam, dam, sretan sam“ koje su darovane dječjim odjelima općih bolnica, dječjim domovima, domovima zdravlja i pedijatrijskim ambulantama, Crvenomu križu, dječjim vrtićima, udrugama i dr.

\section{Popis literature}

Chadwick, Louise. 2013. „Better Start with Bookstart: Evidence for the Ongoing Benefits of Early Literacy“. U: Prepare for Life! Raising Awareness for Early Literacy Education: Implicatons of the International Conference of Experts. ur. Jorg F. Mass, Simone C. Ehmig, Carolin Seelmann, 156-163. Mainz: Stiftung Lesen.

Čudina Obradović, Mira. 2014. Psihologija čitanja: od motivacije do razumijevanja. Zagreb: Golden marketing - Tehnička knjiga, Učiteljski fakultet Sveučilišta u Zagrebu.

Čunović, Kristina i Alka Stropnik. 2015. „Nacionalna kampanja Čitaj mi! - primjer partnerstva i usklađenosti udruga“. Vjesnik bibliotekara Hrvatske 58 (1/2): 103-120.

Ehmig, Simone C. i Carolin Seelmann. 2013. „Preface. Prepare for Life! Raising Awareness for Early Literacy Education: Implicatons of the International Conference of Experts“. U: Prepare for Life! Raising Awareness for Early Literacy Education: Implicatons of the International Conference of Experts. ur. Jorg F. Mass, Simone C. Ehmig, Carolin Seelmann, 9-17. Mainz: Stiftung Lesen. 
Koźmińska, Irena. 2013. „The Most Important Human Capacities Are Being Developed at Home“. U: Prepare for Life! Raising Awareness for Early Literacy Education: Implicatons of the International Conference of Experts. ur. Jorg F. Mass, Simone C. Ehmig, Carolin Seelmann, 141-144. Mainz: Stiftung Lesen.

Lonigan, Chiristopher J. 2013. „The Developmental Significance and Development of Early Literacy Skills“. U: Prepare for Life! Raising Awareness for Early Literacy Education: Implicatons of the International Conference of Experts. ur. Jorg F. Mass, Simone C. Ehmig, Carolin Seelmann, 33-40. Mainz: Stiftung Lesen.

Monaco, Roseliv Aparecida. 2013. „Reading and Playing: The Contributions of Children's Social-cognitive Aspects of Learning“. U: Prepare for Life! Raising Awareness for Early Literacy Education: Implicatons of the International Conference of Experts. ur. Jorg F. Mass, Simone C. Ehmig, Carolin Seelmann, 69-79. Mainz: Stiftung Lesen.

Nickel, Sven. 2013. „Family Literacy: A Short Overview“. U: Prepare for Life! Raising Awareness for Early Literacy Education: Implicatons of the International Conference of Experts. ur. Jorg F. Mass, Simone C. Ehmig, Carolin Seelmann, 144-150. Mainz: Stiftung Lesen.

Radonić, Marija i Ivanka Stričević. 2009. „Rođeni za čitanje: promocija ranog glasnog čitanja djeci od najranije dobi“. Paediatria Croatica 53 (1): 7-11.

Smjernice za knjižnične usluge za bebe $i$ djecu rane dobi. 2008. Zagreb: Hrvatsko knjižničarsko društvo.

Smjernice za knjižnične usluge za djecu. 2004. Zagreb: Hrvatsko knjižničarsko društvo.

Stričević, Ivanka. 2007. „Rana pismenost u kontekstu ključnih kompetencija za cjeloživotno učenje“. Dijete i društvo: časopis za promicanje prava djeteta 9 (2): 49-60.

Stričević, Ivanka i Kristina Čunović. 2013. „Knjižnične usluge za djecu rane dobi i roditelje u Hrvatskoj". Vjesnik bibliotekara Hrvatske 56 (3): 47-66.

Stričević, Ivanka i Srećko Jelušić. 2011. „Informacijske potrebe i čitateljski interesi građana Hrvatske“ U: Međunarodni interdisciplinarni stručni skup Knjiga i slobodno vrijeme: zbornik radova. ur. Elli Pecotić i dr., 16-31. Split: Gradska knjižnica Marka Marulića.

Taylor, Denny. 1983. Family Literacy: Young Children Learning to Read and Write. Portsmouth, NH: Heinemann.

Visinko, Karol. 2014. Čitanje - poučavanje i učenje. Zagreb: Školska knjiga.

\section{Mrežni izvori}

About Reach Out and Read: Partnering with medical providers to ensure success in school for all of America's children. Dostupno na: <http://www.reachoutandread.org> (pristup 15. ožujka 2016.).

All of Poland Reads to Kids Foundation. Dostupno na: <http://www.allofpolandreadstokids. org/> (pristup 15. ožujka 2016.).

Čitaj mi!: Nacionalna kampanja za poticanje čitanja naglas djeci od najranije dobi. Dostupno na: <http://www.citajmi.info/> (pristup 15. ožujka 2016.).

Čitajmo im od najranije dobi. Dostupno na: <http://www.hkdrustvo.hr/hr/projekti/citajmo im_od_najranije_dobi/> (pristup 15. ožujka 2016.).

Every Czech Reads to Kids: About the Project. Dostupno na: $<$ http://www.celeceskoctedetem. $\mathrm{cz} / \mathrm{gb} />$ (pristup 15. ožujka 2016.).

Informativno-edukativni paket za novorođenčad i njihove roditelje. Dostupno na: $<\mathrm{http}: / /$ www.hcd.hr/?sel=68> (pristup 15. ožujka 2016.). 
Konvencija o pravima djeteta (1989). Dostupno na: <http://www.unicef.hr/upload/file/300/ 150215/FILENAME/Konvencija_20o_20pravima_20djeteta.pdf $>$ (pristup 15. ožujka 2016.).

Lesestart - Drei Meilensteine für das Lesen: Das bundesweite frühkindliche Leseförderprogramm. Dostupno na: <https://www.stiftunglesen.de/> (pristup 15. ožujka 2016.).

Mažojo Princo Fondas: Visa Lietuva skaito vaikams. Dostupno na: <http://www.vlsv.lt/ joomla/index.php?lang=lt $>$ (pristup 15. ožujka 2016.).

Nascuts per llegir. Dostupno na: <http://www.cobdc.org/nascutsperllegir/> (pristup 15. ožujka 2016.).

Nati per Leggere: Prezentatione. Dostupno na: <http://www.natiperleggere.it/> (pristup 15. ožujka 2016.).

Podjela Informativno-edukativnih paketa za novorođenčad i njihove roditelje. Dostupno na: $<\mathrm{http}$ ://www.nkc-sisak.hr/> (pristup 15. ožujka 2016.).

Poučavanje čitanja u Europi: konteksti, politike, prakse. Izvršna agencija za obrazovanje, audiovizualnu politiku i kulturu (EACEA P9 Eurydice), Mreža Eurydice, Bruxelles. Dostupno na: <http://eacea.ec.europa.eu/education/eurydice> (pristup 15. ožujka 2016.).

Predstavljanje projekta Knjige za bebe. Dostupno na: <http://www.knjiznica-koprivnica. $\mathrm{hr} />$ (pristup 15. ožujka 2016.).

Program Bebe u knjižnici. Dostupno na: <http://www.gkka.hr/LETAK\%20bebe_novi\%20 logo.pdf $>$ (pristup 15. ožujka 2016.).

Rođeni za čitanje: predavanje prim. mr. sc. Marije Radonić. Dostupno na: <http://gkr.hr/ Magazin/> (pristup 15. ožujka 2016.).

Save the Children: Born to Read Project. Dostupno na: <http://www.savethechildren. org.uk/about-us/where-we-work/united-kingdom/born-to-read> (pristup 15. ožujka 2016.).

Singapure infopedia: Born to Read, Read to Bond programme. Dostupno na: <http:// eresources.nlb.gov.sg/infopedia/articles/SIP_278_2005-01-24.html> (pristup 15. ožujka 2016.).

Stručni skup: Roditelji s bebama i malom djecom - dobro došli u knjižnicu! Dostupno na: $<$ http://www.hkdrustvo.hr/hr/strucna_tijela/17/publikacija/76/> (pristup 15. ožujka 2016.).

The Library of Birmingham: Bookstart. Dostupno na: $<$ http://www.libraryofbirmingham. com/article/childrenunder5/bookstart> (pristup 15. ožujka 2016.).

UNESCO: Interview with the Family Literacy program (FLY) in Hamburg, 2010 UNESCO Literacy Prize Laureate. Dostupno na: <http://www.unesco.org/new/en/education/ themes/education-building-blocks/literacy/literacy-prizes/FLY/> (pristup 15. ožujka 2016.). 


\section{Kristina Čunović}

City Library Ivan Goran Kovačić, Karlovac, Croatia

Stadtbibliothek „Ivan Goran Kovačić “, Karlovac, Kroatien

\section{Alka Stropnik}

Zagreb City Libraries, Zagreb, Croatia

Bibliotheksverbund der Stadt Zagreb, Zagreb, Kroatien

\section{Campaigns, Projects and Programmes Promoting Reading Aloud to Children from an Early Age}

Since 2013, several local programmes have been conducted in Croatia with the aim of promoting and stimulating reading to children at an early age; however, no such project or campaign had previously existed at the national level. Prompted by this information, the Children and Youth Services Commission of the Croatian Librarian Association contacted potential partners with the suggestion of using the occasion of the European Year of Reading Aloud (2013) to launch the first Croatian national campaign aimed at promoting reading aloud to children from birth. The campaign would gradually expand to include librarians, paediatricians, maternity wards and associations dedicated to the rights of children from the earliest age. This paper provides an overview of all global programmes and projects aimed at promoting reading aloud to children from birth and empowering parents. National libraries play an important role in such programmes and projects. The paper also briefly presents reading programmes in Croatia conducted at the local level. Special attention is given to the Croatian national campaign promoting reading aloud to children from the earliest age, Read to me!, launched in 2013. The paper presents the results of the campaign in its three years of existence.

Keywords: early literacy, family literacy, Croatian reading campaign, national reading campaigns and projects

\section{Werbekampagnen, Projekte und Programme zur Förderung des lauten Vorlesens für Kleinstkinder}

In Kroatien wurden bis 2013 mehrere lokale Programme zur Förderung des Vorlesens für Kleinkinder durchgeführt, ohne dass dies durch ein nationales Projekt abgedeckt wurde. Ausgehend davon schlug der Ausschuss für kinder- und jugendliche Dienstleistungen des Kroatischen Bibliothekarsverbands den potentiellen Partnern vor, dass man anlässlich des Europäischen Jahres des lauten Vorlesens (2013) die erste nationale Werbekampagne zur Förderung des lauten Vorlesens für Kleinstkinder startet, in die Bibliothekare, Kinderärzte und Entbindungsanstalten sowie Organisationen für die Wahrung der Kinderrechte systematisch eingebunden waren. Im Beitrag bietet man einen internationalen Überblick über die Programme und Projekte zur Förderung des Vorlesens für Kleinstkinder, in denen die öffentlichen Bibliotheken eine wichtige Rolle spielten. Zugleich werden in aller Kürze Programme zur Förderung des Vorlesens, die in Kroatien auf lokaler Ebene realisiert werden, vorgestellt, insbesondere die kroatische nationale Werbekampagne Lies mir vor!, die 2013 startete und deren Ergebnisse drei Jahre danach spürbar sind.

Schlüsselwörter: früheste Lesefähigkeit, Lesefähigkeit in der Familie, kroatische Kampagne zur Leseförderung, nationale Kampagnen und Projekte zur Leseförderung 


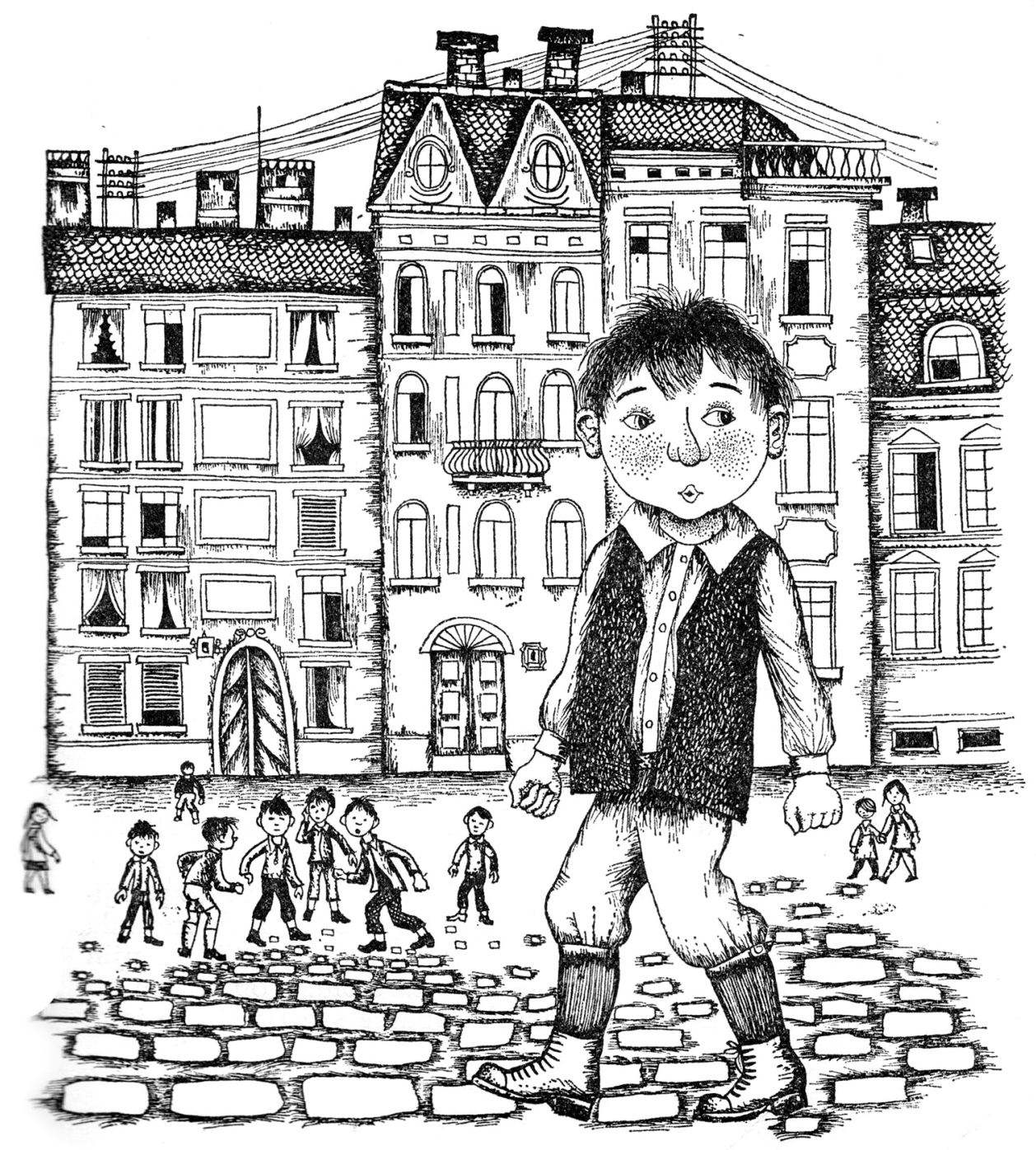

Biblioteka Vjeverica. / Book series Vjeverica.

Mato Lovrak. 1971. Neprijatelj broj 1. Ilus. / Illus. Danica Rusjan, str. / p. 148. 